\title{
Kepatuhan WPOP Usahawan Sebelum dan Sesudah Kebijakan Tax Amnesty Di KPP Pratama Jakarta Pancoran
}

\author{
Dona Fitria $^{1}$, Ismail Dwi Cahyo ${ }^{2}$ \\ Universitas Indraprasta PGRI ${ }^{1,2}$
}

\begin{abstract}
The purpose of this study was to determine and analyze the WPOP Business compliance before and after the tax amnesty was implemented at KPP Pratama Jakarta Pancoran. The data analysis technique in this study uses the $2016-2017$ SPT tax compliance ratio. Statistical tests using the Paried Sample t-Test. The results showed that the number of WPOP business compliance ratios on time after the enactment of the tax amnesty increased by 4.64\%, in 2016 amounting to $9.12 \%$ and in 2017 amounting to 13.76\%. The number of Business WPOPs that report annual SPT not on time after the enactment of the tax amnesty has decreased from 577 to 164. The results of the WPOP Business Compliance ratio not on time after the enactment of the tax amnesty dropped from 2016 by $6.97 \%$ to only $1.91 \%$ in in 2017. However, the number of Business WPOPs that did not report Annual Tax Returns after the enactment of the tax amnesty increased from 2016 to 6,922 to 7,238 in 2017. The ratio of taxpayer compliance that does not submit Annual Tax Returns increases $0.43 \%$. The statistical results using a different paired test can be concluded that there is no difference in compliance of the WPOP Entrepreneurs before and after the enactment of the Tax Amnesty at the Pancoran Primary Tax Office. It means that the Directorate General of Taxes has not succeeded in increasing the compliance of the Business WPOP through the Tax Amnesty policy regulations.
\end{abstract}

Keywords: WPOP compliance, Tax Amnesty, Ratio Analysis, Paired Sample tTest

\section{Pendahuluan}

Tingkat kepatuhan wajib pajak perorangan untuk menunaikan kewajiban pembayaran pajak di Indonesia masih cukup rendah. Hal ini dapat dilihat dari rendahnya rasio pajak terhadap PDB (tax ratio) yang berada pada kisaran $11 \%$ data tahun 2016. Rasio ini jelas masih relatif rendah jika dibandingkan dengan rata-rata dunia ataupun Negara OECD (keduanya sekitar 14\%) Indonesia masih dapat dianggap kondisi undertaxing. Dengan jumlah penduduk berada di peringkat ke-5 terbesar di dunia, sudah selayaknya Indonesia mempunyai banyak potensi pajak 
yang mampu digali (Aryobimo, 2012). Masih belum optimalnya pemungutan pajak menyebabkan tax ratio Indonesia menjadi lebih rendah bila dibandingkan dengan negara-negara di kawasan Asia Tenggara.

Menurut Mardiasmo (2014), setoran pajak dari kelompok wajib pajak orang pribadi sejauh ini terlalu rendah. Terutama, wajib pajak dari kalangan non karyawan atau memiliki pekerjaan sendiri termasuk usaha profesi. Hal ini menunjukkan bahwa wajib pajak orang pribadi seperti pengusaha dan profesi belum memenuhi kewajiban pajaknya dengan baik. Rendahnya tingkat kepatuhan pajak menjadi indikator rendahnya serapan pajak oleh pemerintah.

Sampai saat ini pemerintah sedang berusaha untuk meningkatkan pembangunan infrastruktur, dengan pertimbangan pembangunan infrastruktur yang baik akan memberikan multiplier effect yang besar dan berkelanjutan terhadap perekonomion nasional. Pembangunan infrastruktur juga diharapkan dapat menjadi pemicu percepatan pemerataan pembangunan di seluruh wilayah Indonesia. Hal ini dapat dilihat dari keseriusan pemerintah yang aktif menggalakan pembangunan infrastrukur di berbagai bidang, baik infrastruktur darat, laut maupun udara seperti pembangunan jalan tol, jalan trans, jembatan, pelabuhan, tol laut, bandara, dan lainlain. Gencarnya pembangunan infrastruktur tersebut tentu membutuhkan dana yang sangat besar. Pada tahun 2016, anggaran infrastruktur dalam Anggaran Pendapatan dan Belanja Negara (APBN) Tahun 2016 mencapai Rp 313,5 triliun. Angka ini naik signifikan dibandingkan APBN-Perubahan (APBN-P) Tahun 2015 yang hanya sebesar Rp290,3 triliun. Hal ini menjadi masalahkarena sumber penerimaan negara sekitar 75 persen berasal dari sektor pajak dan saat bersamaan realisasinya tidak pernah tercapai, kecuali tahun 2011, bahkan kecenderungannya mengalami penurunan.

Dalam berbagai hasil penelitian, Supadmi (2010) mengatakan bahwa kepatuhan wajib pajak dapat diketahui dengan criteria antara lain; wajib pajak paham atau berusaha untuk memahami semua ketentuan peraturan perundangundangan perpajakan, mengisi formulir pajak dengan lengkap dan jelas, menghitung jumlah pajak yang terutang dengan benar, membayar pajak yang terutang tepat pada waktunya. Sedangkan Muliari dan Setiawan (2010) 
menjelaskan bahwa kriteria wajib pajak patuh menurut Keputusan Menteri Keuangan No.544/KMK.04/2000 wajib pajak patuh adalah sebagai berikut; tepat waktu dalam menyampaikan SPT untuk semua jenis pajak dalam dua tahun terakhir, tidak mempunyai tunggakan pajak untuk semua jenis pajak, kecuali telah memperoleh izin untuk mengangsur atau menunda pembayaran pajak, tidak pernah dijatuhi hukuman karena melakukan tindak pidana di bidang perpajakan dalam jangka waktu 10 tahun terakhir, dan dalam dua tahun terakhir menyelenggarakan pembukuan dan dalam hal terhadap wajib pajak pernah dilakukan pemeriksaan, koreksi pada pemeriksaan yang terakhir untuk tiap-tiap jenis pajak yang terutang paling banyak lima persen.

Menanggapi permasalahan ketidakpatuhan wajib pajak, menurut Cahyonowati (2011), kepatuhan wajib pajak pribadi dapat ditingkatkan melalui mekanisme denda dan pemeriksaan pajak (variabel economic deterrence) yang dipaksakan (enforced tax compliance). Tetapi berdasarkan penelitian Kogler et al. (2013) dan Kircheler et al. (2008), mekanisme denda dan pemeriksaan pajak menjadi kurang efektif meningkatkan kepatuhan sukarela bila dilakukan dalam jangka panjang.

Salah satu upaya nyata yang dilakukan pemerintah Indonesia adalah dengan dilaksanakannya program pengampunan pajak (tax amnesty). Banyak kondisi yang melatar belakangi keputusan pemerintah untuk menjalankan program pengampunan pajak. Kondisi tersebut antara lain adalah tidak tercapainya target pengumpulan pajak pada tahun 2015, tingkat kepatuhan wajib pajak yang masih rendah, perlunya basis data wajib pajak baru yang lebih kredibel serta adanya Automatic Exchange Information antar negara di dunia yang akan diberlakukan pada tahun 2018 .

Dalam Undang-undang No. 11 Tahun 2016, pasal 1 (1) yang dimaksud dengan Pengampunan Pajak adalah penghapusan pajak yang seharusnya terutang, tidak dikenai sanksi administrasi perpajakan dan sanksi pidana dibidang perpajakan dengan cara mengungkap harta dan membayar uang tebusan. Pada pasal 1 (3), Harta yang dimaksud adalah akumulasi tambahan kemampuan ekonomis berupa seluruh kekayaan baik berwujud maupun tidak berwujud, baik bergerak maupun tidak 
bergerak, baik yang digunakan untuk usaha maupun bukan untuk usaha, yang berada di dalam dan/atau di luar wilayah Negara Kesatuan Republik Indonesia. Sedangkan pada pasal 1 (7), uang tebusan adalah sejumlah uang yang dibayarkan ke kas negara untuk mendapatkan Pengampunan Pajak.

Pengampunan pajak atau amnesti pajak (bahasa Inggris: tax amnesty) adalah sebuah kesempatan berbatas waktu bagi kelompok wajib pajak tertentu untuk membayar pajak dengan jumlah tertentu sebagai pengampunan atas kewajiban membayar pajak (termasuk dihapuskannya bunga dan denda) yang berkaitan dengan masa pajak sebelumnya tanpa takut penuntutan pidana (https://id.wikipedia.org/wiki/Pengampunan_pajak).

Pengampunan Pajak pada tahun 2016 dibagi menjadi beberapa periode, yaitu : periode pertama dimulai pada 1 Juli 2016 dan akan berakhir pada tanggal 30 September 2016 sedangkan periode Pengampunan Pajak periode kedua dimulai pada 1 Oktober 2016 dan akan berakhir pada tanggal 31 Desember 2016, Sedangkan periode ketiga dimulai 1 Januari 2017 sampai dengan 31 Maret 2017. Kebijakan perpajakan yang pernah dilakukan Indonesia sebelum tahun 2016 adalah antara lain program pengampunan pajak ( tax amnesty ) pada tahun 1964 dan 1984, serta program sunset policy yang dianggap program tax amnesty versi mini pada tahun 2008.

Pada hakekatnya implementasi tax amnesty maupun sunset policy sekalipun secara psikologis sangat tidak memihak pada wajib pajak yang selama ini taat membayar pajak. Kalaupun kebijakan itu diterapkan di suatu negara, harus ada kajian mendalam mengenai karakteristik wajib pajak yang ada di suatu negara tersebut karena karakteristik wajib pajak tentu saja berbeda-beda. Bagi banyak negara, pengampunan pajak (tax amnesty) seringkali dijadikan alat untuk menghimpun penerimaan negara dari sektor pajak (tax revenue) secara cepat dalam jangka waktu yang relatif singkat. Program tax amnesty ini dilaksanakan karena semakin parahnya upaya penghindaran pajak. Kebijakan ini dapat memperoleh manfaat perolehan dana, terutama kembalinya dana yang disimpan di luar negeri, dan kebijakan ini mempunyai kelemahan dalam jangka panjang dapat berakibat buruk berupa menurunnya kepatuhan sukarela (voluntary compliance) dari wajib 
pajak patuh, bilamana tax amnesty dilaksanakan dengan program yang tidak tepat.

Sebagian ahli perpajakan berpendapat bahwa tax amnesty merupakan cara yang mujarab untuk meningkatkan kepatuhan pajak. Walau demikian, ada juga kekhawatiran bahwa tax amnesty dapat melemahkan kepatuhan wajib pajak, terutama jika orang berharap bahwa tax amnesty mungkin akan datang lagi di masa depan (Darussalam dkk, 2014).

\section{Metode Penelitian}

Penelitian ini menggunakan penelitian deskriptif kualitatif, yaitu penelitian yang dilakukan pada kondisi objek yang alamiah tanpa adanya manipulasi, dimana peneliti sebagai instrumen kunci, Sugiyono (2010:14). Penelitian ini lebih menitikberatkan pada penelitian lapangan, karena penelitian ini dilakukan dengan cara berhubungan langsung dengan objek penelitian. Penelitian ini dilaksanakan di KPP Pratama Jakarta Pancoran. Subjek dalam penelitian ini adalah Wajib Pajak Orang Pribadi yang mempunyai usaha. Objek penelitian ini adalah Kepatuhan Wajib Pajak Orang Pribadi setelah berlakunya kebijakan Tax Amnesty.

Data dalam penelitian ini dikumpulkan dengan teknik dokumentasi dan wawancara. Data yang dibutuhkan meliputi jumlah data WPOP Usaha yang menyampaikan SPT Tahunan dan jumlah WPOP terdaftar di KPP Pratama Jakarta Pancoran tahun 2016 sampai dengan tahun 2017. Peneliti menggunakan wawancara tidak terstruktur, peneliti tidak menggunakan pedoman wawancara atau secara sistematis, pedoman peneliti berupa garis-garis besar permasalahan Kepatuhan WPOP Usaha, permasalahan kebijakan tax amnesty, dan Penyampaian SPT Tahunan.

Teknik analisis data menggunakan analisis rasio kepatuhan dan analisis uji beda kepatuhan wajib pajak dengan Paired Sample t-test. Untuk analisis rasio kepatuhan antara lain; rasio kepatuhan wajib tepat waktu, rasio kepatuhan wajib pajak tidak tepat waktu, dan rasio kepatuhan wajib pajak tidak menyampaikan SPT tahunan baik yang terjadi di tahun 2016 maupun tahun 2017 dapat dihitung dengan rumus sebagai berikut:

$$
\frac{\text { SPT Tahunan WPOP tepat waktu }}{\text { WPOP Terdaftar wajib SPT Tahunan }} \times 100 \%
$$


Peraturan Menteri Keuangan Republik Indonesia No:74/PMK.03/2012 mengatur bahwa Wajib Pajak disebut Wajib Pajak patuh apabila memenuhi beberapa persyaratan, salah satunnya adalah tepat waktu dalam menyampaikan SPT. Wajib Pajak yang patuh adalah Wajib Pajak yang melaksanakan kewajibannya sesuai dengan ketentuan peraturan perundang-undangan perpajakan.

$$
\frac{\text { SPT Tahunan WPOP tidak tepat waktu }}{\text { WPOP Terdaftar wajib SPT Tahunan }} \times 100 \%
$$

Jumlah SPT Tahunan WPOP yang digunakan dalam perhitungan ini adalah SPT Tahunan WPOP yang tidak tepat waktu yaitu disampaikan lebih dari tiga bulan setelah akhir Tahun Pajak.

$$
\frac{\text { SPT Tahunan WPOP tidak melaporkan SPT }}{\text { WPOP Terdaftar wajib SPT Tahunan }} \times 100 \%
$$

Jumlah WPOP yang tidak menyampaikan SPT Tahunan dalam perhitungan ini adalah selisih antara jumlah WPOP terdaftar yang wajib SPT Tahunan dengan jumlah seluruh penerimaan SPT Tahunan WPOP selama satu tahun.

Sedangkan untuk analisis uji beda kepatuhan wajib pajak sebelum dan sesudah kebijakan tax amnesty, terlebih dahulu ditentukan uji normalitas. Sampel yang digunakan dalam uji beda adalah saling berhubungan dan jika hasil uji normalitas menunjukan sampel berdistribusi normal maka uji beda yang digunakan dalam penelitian ini adalah uji parametik (Paired sample t-test). Tetapi jika sampel tidak berdistribusi normal maka uji beda yang akan digunakan dalam penelitian ini adalah uji non-parametik (Wilcoxon Signed Rank Test).

\section{Hasil Dan Pembahasan}

Berdasarkan hasil studi dokumentasi yang telah dilaksanakan di KPP Pratama Jakarta Pancoran dapat disajikan tabel ringkasan mengenai WPOP Usaha yang menyampaikan SPT Tahunan tepat waktu, tidak tepat waktu, dan tidak melaporkan sebagai berikut: 
Tabel 1. Jumlah WPOP Usaha yang menyampaikan SPT Tahunan Tahun 2016 dan 2017

\begin{tabular}{lcc}
\hline \multirow{2}{*}{ Bulan } & \multicolumn{2}{c}{ Tahun } \\
\cline { 2 - 3 } & $\mathbf{2 0 1 6}$ & $\mathbf{2 0 1 7}$ \\
\hline Januari & 2 & 7 \\
\hline Februari & 39 & 51 \\
\hline Maret & 712 & 678 \\
\hline April & 74 & 446 \\
\hline Mei & 10 & 19 \\
\hline Juni & 11 & 9 \\
\hline Juli & 6 & 13 \\
\hline Agustus & 16 & 22 \\
\hline September & 121 & 11 \\
\hline Oktober & 33 & 11 \\
\hline November & 17 & 8 \\
\hline Desember & 66 & 7 \\
\hline Lebih dari 31 & 223 & 64 \\
Des & $\mathbf{1 . 3 3 0}$ & $\mathbf{1 . 3 4 6}$ \\
\hline Jumlah & & \\
\hline
\end{tabular}

Sumber: Seksi Pengolahan Data dan Informasi KPP Pratama Jakarta Selatan 2018

Tabel 2. Jumlah WPOP Usaha yang Menyampaikan SPT Tahunan Tepat Waktu, Tidak Tepat Waktu dan Tdak Melaporkan

\begin{tabular}{ccccc}
\hline Tahun & $\begin{array}{c}\text { Tepat } \\
\text { Waktu }\end{array}$ & $\begin{array}{c}\text { Tidak Tepat } \\
\text { Waktu }\end{array}$ & $\begin{array}{c}\text { Tidak } \\
\text { Melaporkan }\end{array}$ & $\begin{array}{c}\text { Jumlah WPOP } \\
\text { Usaha } \\
\text { Terdaftar }\end{array}$ \\
\hline $\mathbf{2 0 1 6}$ & 753 & 577 & 6.922 & 8.252 \\
\hline $\mathbf{2 0 1 7}$ & 1.182 & 164 & 7.238 & 8.584 \\
\hline
\end{tabular}

Sumber: Seksi Pengolahan Data dan Informasi KPP Pratama Jakarta Selatan 2018 


\section{Rasio Kepatuhan Wajib Pajak Sebelum Berlaku Tax Amnesty Tahun 2016}

Selanjutnya hasil perhitungan tabel berikut ini menunjukkan bahwa rasio kepatuhan WP yang menyampaikan SPT tepat waktu mengalami perubahan. Jumlah WPOP Usaha tepat waktu sebelum berlakunya tax amnesty 2016 sebanyak 753 dengan rasio kepatuhan WP sebesar 9,12\%. Rasio Kepatuhan WP paling tinggi sebesar $12,70 \%$ pada bulan Maret.

\section{Tabel 3. Jumlah WPOP Usaha yang Menyampaikan SPT Tahunan Tepat} Waktu Tahun 2016

\begin{tabular}{lcc}
\hline Bulan & $\begin{array}{r}\text { WPOP } \\
\text { Tepat } \\
\text { Waktu }\end{array}$ & $\begin{array}{c}\text { Rasio } \\
(\boldsymbol{\%})\end{array}$ \\
\hline Januari & 2 & 0,02 \\
\hline Februari & 39 & 0,47 \\
\hline Maret & 712 & 8,63 \\
\hline Jumlah & $\mathbf{7 5 3}$ & $\mathbf{9 , 1 2}$ \\
\hline
\end{tabular}

Sumber: Olahan Data 2018

Sementara hasil perhitungan pada tabel 4 berikut ini menunjukkan bahwa rasio kepatuhan WP yang tidak tepat waktu menyampaikan SPT Tahunan tahun 2016 selalu mengalami perubahan. Jumlah WPOP Usaha tidak tepat waktu sebelum berlaku tax amnesty sebanyak 164 dengan rasio ketidakpatuhan WP sebesar 6,97\%. Rasio Ketidakpatuhan WP paling tinggi sebesar 3,50\% pada bulan Desember. 
Tabel 4. Jumlah WPOP Usaha yang Menyampaikan SPT Tahunan Tidak Tepat Waktu Tahun 2016

\begin{tabular}{lcc}
\hline Bulan & $\begin{array}{c}\text { WPOP Tidak } \\
\text { Tepat Waktu }\end{array}$ & $\begin{array}{c}\text { Rasio } \\
(\boldsymbol{\%})\end{array}$ \\
\hline April & 74 & 0,89 \\
\hline Mei & 10 & 0,12 \\
\hline Juni & 11 & 0,13 \\
\hline Juli & 6 & 0,07 \\
\hline Agustus & 16 & 0,19 \\
\hline September & 121 & 1,47 \\
\hline Oktober & 33 & 0,39 \\
\hline November & 17 & 0,21 \\
\hline Desember & 289 & 3,50 \\
\hline Jumlah & $\mathbf{5 7 7}$ & $\mathbf{6 , 9 7}$ \\
\hline Sumber: Olahan Data 2018 &
\end{tabular}

Kemudian hasil perhitungan berdasatkan tabel 5 di bawah ini menunjukkan bahwa jumlah WPOP Usaha yang tidak menyampaikan SPT Tahunan sebanyak 6.922 dengan rasio WP tidak melapor sebesar $83,88 \%$.

Tabel 5. Jumlah WPOP Usaha yang Tidak Menyampaikan SPT Tahunan 2016

\begin{tabular}{lccc}
\hline Tahun & $\begin{array}{c}\text { WPOP } \\
\text { Terdaftar }\end{array}$ & $\begin{array}{c}\text { WPOP Tidak } \\
\text { Menyampaikan }\end{array}$ & $\begin{array}{c}\text { Rasio } \\
(\boldsymbol{\%})\end{array}$ \\
\hline 2016 & 8.252 & 6.922 & 83,88 \\
\hline Jumlah & $\mathbf{8 . 2 5 2}$ & $\mathbf{6 . 9 2 2}$ & $\mathbf{8 3 , 8 8}$ \\
\hline
\end{tabular}

Sumber: Olahan Data 2018 
Rasio Kepatuhan Wajib Pajak Sesudah Berlaku Tax Amnesty Tahun 2017

Tabel 6. Jumlah WPOP Usaha yang Menyampaikan SPT Tahunan Tepat Waktu Tahun 2017

\begin{tabular}{lcc}
\hline \multicolumn{1}{c}{ Bulan } & $\begin{array}{c}\text { WPOP Tepat } \\
\text { Waktu }\end{array}$ & Rasio (\%) \\
\hline Januari & 7 & 0,08 \\
\hline Februari & 51 & 0,59 \\
\hline Maret & 678 & 7,89 \\
\hline April & 446 & 5,20 \\
\hline Jumlah & $\mathbf{1 . 1 8 2}$ & $\mathbf{1 3 , 7 6}$ \\
\hline
\end{tabular}

Sumber: Olahan Data 2018

Hasil perhitungan tabel di atas menunjukkan bahwa rasio kepatuhan WP yang menyampaikan SPT tepat waktu mengalami perubahan. Jumlah WPOP Usaha tepat waktu sesudah berlakunya tax amnesty 2017 sebanyak 1.182 dengan rasio kepatuhan WP sebesar 13,76\%. Rasio Kepatuhan WP paling tinggi sebesar 7,89\% pada bulan Maret.

a) Rasio Kepatuhan Wajib Pajak Tidak Tepat Waktu

Tabel 7. Jumlah WPOP Usaha yang Menyampaikan SPT Tahunan Tidak Tepat Waktu Tahun 2017

\begin{tabular}{lcc}
\hline Bulan & $\begin{array}{c}\text { WPOP Tidak } \\
\text { Tepat Waktu }\end{array}$ & $\begin{array}{c}\text { Rasio } \\
(\boldsymbol{\%})\end{array}$ \\
\hline Mei & 19 & 0,22 \\
\hline Juni & 9 & 0,10 \\
\hline Juli & 13 & 0,15 \\
\hline Agustus & 22 & 0,26 \\
\hline September & 11 & 0,13 \\
\hline Oktober & 11 & 0,13 \\
\hline
\end{tabular}




\begin{tabular}{lcc}
\hline November & 8 & 0,09 \\
\hline Desember & 71 & 0,83 \\
\hline Jumlah & $\mathbf{1 6 4}$ & $\mathbf{1 , 9 1}$ \\
\hline
\end{tabular}

Sumber: Olahan Data 2018

Hasil perhitungan tabel menunjukkan bahwa rasio kepatuhan WP yang tidak tepat waktu menyampaikan SPT Tahunan tahun 2017 mengalami perubahan. Jumlah WPOP Usaha tidak tepat waktu sesudah berlaku tax amnesty sebanyak 164 dengan rasio ketidakpatuhan WP sebesar 1,91\%. Rasio Kepatuhan WP paling tinggi sebesar 0,83\% pada bulan Desember.

b) Rasio Kepatuhan Wajib Pajak tidak Menyampaikan SPT Tahunan

Tabel 8. Jumlah WPOP Usaha yang Tidak Menyampaikan SPT Tahunan 2017

\begin{tabular}{lccc}
\hline Tahun & $\begin{array}{c}\text { WPOP } \\
\text { Terdaftar }\end{array}$ & $\begin{array}{c}\text { WPOP Tidak } \\
\text { Menyampaikan }\end{array}$ & Rasio (\%) \\
\hline 2017 & 8.584 & 7.238 & 84,31 \\
\hline Jumlah & $\mathbf{8 . 5 8 4}$ & $\mathbf{7 . 2 3 8}$ & $\mathbf{8 4 , 3 1}$ \\
\hline \multicolumn{2}{r}{ Sumber: Olahan Data 2018} & &
\end{tabular}

Sumber: Olahan Data 2018

Hasil perhitungan tabel di atas menunjukkan bahwa jumlah WPOP Usaha yang tidak menyampaikan SPT Tahunan sebanyak 7.238 dengan rasio WP tidak melapor sebesar $84,31 \%$.

\section{Analisis Uji Beda}

Tabel 9. Analisis Statistik Deskriptif WPOP Usaha yang Patuh

Sebelum dan Sesudah Tax Amnesty

Paired Samples Statistics

\begin{tabular}{|c|c|c|c|c|c|}
\hline & \multicolumn{3}{|r|}{ Std. } & \multirow{2}{*}{$\begin{array}{c}\text { Std. Error } \\
\text { Mean }\end{array}$} \\
\hline & & Mean & $\mathrm{N}$ & Deviation & \\
\hline \multirow[t]{2}{*}{ Pair 1} & Sebelum & 206.75 & 4 & 338.114 & 169.057 \\
\hline & Sesudah & 295.50 & 4 & 322.474 & 161.237 \\
\hline
\end{tabular}


Berdasarkan tabel 9 di atas, pada group statistics diketahui nilai rata-rata (mean) sebelum tax amnesty 206,00 dengan standar deviasi 338,11 dan sesudah tax amnesty mempunyai nilai rata-rata 295,50 dengan standar deviasi 322,47.

\section{Tabel 10. Korelasi WPOP Usaha yang Patuh Sebelum dan Sesudah Tax Amnesty Paired Samples Correlations}

\begin{tabular}{lllll}
\hline & & \multicolumn{3}{c}{ Correlati } \\
& & N & on & Sig. \\
\hline Pair & Before \& & 4 & .836 & .164 \\
1 & After & & & \\
\hline
\end{tabular}

Diketahui bahwa nilai korelasi sebesar 0,836 dengan nilai probabilitas (sig.) 0,164 . Hal ini menunjukan bahwa korelasi antara sebelum dan sesudah tax amnesty memiliki hubungan tidak berarti, karena nilai probabilitas $>0,05$.

\section{Tabel 11. Hasil Uji Kepatuhan WPOP Sebelum dan Sesudah Tax} Amnesty

\begin{tabular}{|c|c|c|c|c|c|c|c|c|c|}
\hline & & & Pair & d Differe & ices & & & & \\
\hline & & & & & $95 \% \mathrm{Col}$ & fidence & & & \\
\hline & & & & Std. & Interva & of the & & & Sig. \\
\hline & & & Std. & Error & Diffe & ence & & & $(2-$ \\
\hline & & Mean & Deviation & Mean & Lower & Upper & $\mathrm{t}$ & $\mathrm{df}$ & tailed) \\
\hline $\begin{array}{l}\text { Pair } \\
1\end{array}$ & $\begin{array}{l}\text { Sebelum - } \\
\text { Sesudah }\end{array}$ & -88.75 & 189.92 & 94.96 & -390.95 & -213.45 & -.935 & 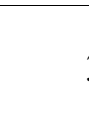 & .419 \\
\hline
\end{tabular}

Berdasarkan tabel 11. mengenai uji beda (paired samples test) diketahui $\mathrm{t}$ hitung $-0,935<\mathrm{t}$ tabel 1,895. Nilai probabilitas $0,419>0,05$ maka $\mathrm{H}_{0}$ diterima. Hal ini dapat disimpulkan bahwa tidak ada perbedaan kepatuhan WPOP Usahawan sebelum dan sesudah berlakunya tax amnesty.

Hasil penelitian berbeda dengan penelitian Jacques (2010) yang menunjukan 
bahwa tax amnesty secara parsial berpengaruh positif dan signifikan terhadap tingkat kepatuhan wajib pajak dengan nilai signifikansi lebih kecil dari 0,05. Junpath (2013) meneliti mengenai multi tax amnesty dan kepatuhan pajak di Afrika Selatan. Penelitian kuantitatif menggunakan metode kuesioner ini menyimpulkan bahwa tax amnesty meningkatkan penerimaan pajak dan kepatuhan di Afrika Selatan, sejalan dengan penelitian Ngadiman dan Huslin (2015) yang meneliti tentang pengaruh sunset policy dan tax amnesty terhadap kepatuhan wajib pajak mendapatkan hasil bahwa tax amnesty berpengaruh positif terhadap tingkat kepatuhan wajib pajak.

\section{Kesimpulan}

Jumlah WPOP Usaha yang melaporkan SPT Tahunan tepat waktu setelah berlakunya tax amnesty sebanyak 1.182 WP,. Rasio kepatuhan WPOP Usahawan tepat waktu setelah berlakunya tax amnesty meningkat sebesar 4,64\%, pada tahun 2016 sebesar 9,12\% dan tahun 2017 sebesar 13,76\%. Selanjutnya, jumlah WPOP Usaha yang melaporkan SPT Tahunan tidak tepat waktu setelah berlakunya tax amnesty berkurang dari 577 menjadi 164. Hasil rasio kepatuhan WPOP Usaha tidak tepat waktu setelah berlakunya tax amnesty turun dari tahun 2016 sebesar 6,97\% menjadi hanya $1,91 \%$ di tahun 2017. Namun, jumlah WPOP Usaha yang tidak melaporkan SPT Tahunan setelah berlakunya tax amnesty bertambah dari tahun 2016 sebanyak 6.922 menjadi 7.238 di tahun 2017 . Oleh karena itu, rasio kepatuhan wajib pajak yang tidak menyampaikan SPT Tahunan naik sebesar 0,43\%, yaitu tahun 2016 sebesar 83,88\% menjadi 84,31\% di 2017. Artinya bahwa tax amnesty belum berhasil meningkatkan WPOP Usahawan untuk aktif kembali sebagai wajib pajak, dimana wajib pajak harus melaporkan, membayarkan kemudian melaporkan SPT Tahunan.

Hasil statistik menggunakan uji beda berpasangan dapat disimpulkan bahwa tidak ada perbedaan kepatuhan WPOP Usahawan sebelum dan sesudah berlakunya Tax Amnesty di KPP Pratama Pancoran. Hal ini ditunjukkan dari hasil pengujian hipotesis menggunakan Paired Sample t-Test yang diperoleh nilai dari t hitung sebesar -0,935 sedangkan $\mathrm{t}$ tabel sebesar 1,895 sehingga $\mathrm{H}_{0}$ diterima. Berarti Direktorat Jenderal Pajak belum berhasil meningkatkan kepatuhan WPOP Usaha 
melalui peraturan kebijakan Tax Amnesty.

Berdasarkan hasil penelitian di atas penulis menyarankan Kepada Direktorat Jendral Pajak harus lebih intens memberikan sosialisasi kepada masyarakat akan pentingnya melaporkan pajak. Sosialisasi paling efektif dilakukan dengan eksekusi atau mendatangi warga Jakarta Selatan yang telah mempunyai usaha sendiri, tanpa memperhatikan besar kecilnya usaha. Selanjutnya, program tax amnesty sangat efektif untuk terus diimplementasikan, karena terbukti memberikan hasil yang berarti bagi pemasukan Negara; Kepada Wajib Pajak baru yang telah mendaftarkan diri langsung diberikan penjelasan mengenai hak dan kewajiban sebagai Wajib Pajak, tidak hanya dalam bentuk $\mathrm{CD}$ atau hard-copy tetapi harus diberikan penjelasan secara lisan. Agar Wajib Pajak memahami betul peran sebagai Wajib Pajak yang patuh sesuai dengan UU perpajakan; Kepada Aparatur perpajakan harus mengawasi wajib pajak ketika wajib pajak mulai lalai dalam membayarkan maupun melaporkan pajakanya, dengan cara selalu memberikan peringatan kepada wajib pajak yang telat dalam membayar ataupun menyampaikan SPT Tahunan. Surat teguran, sebaiknya segera sesudah WP lalai tanpa harus menunggu tahun-tahun berikutnya.

\section{UCAPAN TERIMAKASIH}

Penelitian dan penulisan artikel ini dibiayai oleh Kemenristek Dikti DIPA: Direktorat penelitian dan pengabdian masyarakat No. Kontrak: 032/KM/PNT/2018, Tanggal 6 Maret 2018. dengan skema Penelitian Dosen Pemula. Oleh karena ini tim peneliti mengucapkan terimakasih yang sebesar-besarnya karena telah diberikan kesempatan untuk melakukan pengembangan kapasitas. Penulis juga mengucapkan terima kasih kepada semua pihak terkait antara lain; kepada Kepala Direktorat Jenderal Pajak, khususnya Direktorat Jenderal Pajak wilayah Jakarta Selatan. Tidak lupa penulis mengucapkan terima kasih kepada staff atau pegawai pajak yang begitu kooperatif memberikan kami informasi yang memadai. Terakhir penulis memberikan penghargaan setinggi-tingginya kepada rektorat, dekanat, dan kepala LPPM serta seluruh pegawai di LPPM Universitas Indraprasta PGRI. 


\section{DAFTAR PUSTAKA}

Aryobimo, Putut dan Nur Cahyonowati. 2012. Pengaruh Persepsi Wajib Pajak tentang Kualitas Pelayanan Fiskus terhadap Kepatuhan Wajib Pajak dengan Kondisi Keuangan Wajib Pajak dan Preferensi Risiko sebagai Variabel Moderating (Studi Empiris terhadap Wajib Pajak Orang Pribadi di Kota Semarang). Dipenegoro Journal of Accounting, Volume 1, No. 1, Tahun 2012, hal 2.

Cahyonowati, Nur . 2011. Model Moral dan Kepatuhan Perpajakan: Wajib Pajak Orang Pribadi. Jurnal Akuntansi dan Auditing Indonesia , 15 (2). pp. 161177.

Darussalam, B. Bawono, dkk. 2014. Memahami Ketidakpatuhan Pajak: Inside Tax Edisi 26 Desember 2014.

Direktorat Jendral Pajak. 2015. Penerimaan Pajak. https:// http://www.pajak.go.id/penerimaan-pajak. Diunduh 14 Maret 2017.

Gunadi. 2005. Akuntansi Perpajakan. Jakarta: PT Grasindo http://www.pajak.go.id Tax Ratio Indonesia. Diakses pada 09 juni 2017. https://id.wikipedia.org/wiki/Pengampunan_pajak. Diakses pada 10 Juni 2017. Jacques Malherbe. (2010) “Tax Amnesties in the 2009 Landscape”. Dalam Inside Tax Edisi 15 (Mei, XII). Darussalam: PT Dimensi Internasional Tax. Junpath, Sachin. 2013. Multiple Tax Manesties and Compliance in South Africa. Durban University of Technology.

Keputusan Menteri Keuangan No. 192/KMK.03/2007 Tentang Kriteria Wajib Pajak Patuh.

Kirchler, E., Hoelzl, E., \& Wahl, I. 2008. Enforced versus voluntary tax compliance: The "slippery slope" framework. Journal of Economic Psychology, 29(2), 210-225. doi:10.1016/j.joep.2007.05.004.

Kogler, Christoph, Matthias Kasper and Erich Kirchler. 2013. Tax Policy and the News: An Empirical Analysis of Taxpayers' Perceptions of Taxrelated Media Coverage and its Impact on Tax Compliance. University of Vienna, Austria WU - Vienna University of Economics and Business: International Taxation Research Paper Series No. 2013 - 07. 
Mardiasmo. 2014, Perpajakan. Edisi Revisi. Yogyakarta: Andi.

Muliari, N.K. dan P.E. Setiawan. 2010. Pengaruh Persepsi tentang Sanksi Perpajakan dan Kesadaran Wajib Pajak pada Kepatuhan Pelaporan Wajib Pajak Orang Pribadi di KPP Pratama Denpasar Timur. JurnalAkuntansi dan Bisnis :Fakultas EkonomiUniversitas Udayana.

Sugiono. 2010. Metode Penelitian Kualitatif. Bandung: Alfabeta.

Supadmi. 2010. Meningkatkan Kepatuhan Wajib Pajak Melalui Kualitas. Jurnal Akuntansi dan Bisnis : Fakultas Ekonomi Universitas Udayana.

Undang-Undang Republik Indonesia Nomor 11 Tahun 2016 Tentang Pengampunan Pajak 